Editor's Note: These short reviews of a recent paper in the Journal, written exclusively by graduate students or postdoctoral fellows, are intended to mimic the journal clubs that exist in your own departments or institutions. For more information on the format and purpose of the Journal Club, please see http://www.jneurosci.org/misc/ifa_features.shtml.

\title{
Moderate Reduction of $\gamma$-Secretase: Is There a Therapeutic Sweet Spot?
}

\author{
Se Hoon Choi ${ }^{1}$ and Eric Norstrom ${ }^{2}$ \\ ${ }^{1}$ Committee on Neurobiology and ${ }^{2}$ Department of Neurobiology, University of Chicago, Chicago, Illinois 60637 \\ Review of Li et al. (http://www.jneurosci.org/cgi/content/full/27/40/10849)
}

There is presently no effective treatment for Alzheimer's disease (AD). The deposition of amyloid $\beta(\mathrm{A} \beta)$, a cardinal pathological lesion of $\mathrm{AD}$, suggests that reducing $A \beta$ production could be a promising treatment. $A \beta$ peptides are liberated from amyloid precursor proteins (APP) by sequential cleavage, first by BACE 1 ( $\beta$-site APP-cleaving enzyme 1), an aspartyl protease, and then by $\gamma$-secretase (Sisodia and St George-Hyslop, 2002), a macromolecular complex consisting of presenilin (PS), nicastrin (Nct), anterior pharynx defective-1 (Aph-1), and PS enhancer-2 (Pen-2). Hence, $\gamma$-secretase has been considered a plausible molecular target as a means to interfere with the production of $\mathrm{A} \beta$. However, strong inhibition of $\gamma$-secretase leads to severe adverse effects (Milano et al., 2004), mediated by impaired processing of its multiple in vivo targets. For instance, the $\gamma$-secretase substrate, Notch, plays an important role in cell fate signaling and specification during development, in the differentiation of the intestinal epithelium, and in lymphopoiesis in the adult (Guidos, 2002). Notch also appears to play a role in tumor suppression (Nicolas et al., 2003). Although complete in-

Received 0ct. 24, 2007; revised Nov. 13, 2007; accepted Nov. 13, 2007. We thank Dr. Sangram Sisodia for helpful comments on this manuscript. Correspondence should be addressed to Eric Norstrom, Department of Neurobiology, University of Chicago, 947 E. 58th Street, MC-0926, AB 327, Chicago, IL 60637. E-mail: norstrom@uchicago.edu.

D0I:10.1523/JNEUROSCI.4821-07.2007

Copyright $\odot 2007$ Society for Neuroscience $\quad 0270-6474 / 07 / 2713579-02 \$ 15.00 / 0$ hibition of $\gamma$-secretase is predictably toxic, it is not known whether moderate inhibition could achieve a therapeutic benefit without the side effects. A recent study by Li et al. (2007) in The Journal of Neuroscience addressed this question in vivo using transgenic mice.

The authors first examined mouse lines that expressed varying levels of $\gamma$-secretase complex components. For lines heterozygous for one or more components of $\gamma$-secretase, enzymatic activities ranged from 75 to $36 \%$ of wild-type levels as assayed in embryonic fibroblasts and brain extracts from $P S 1^{+/-}$, Aph$1 a^{+/-}, \mathrm{Nct}^{+/-}$, and $\mathrm{Nct}{ }^{+/-} ; \mathrm{PS} 1^{+/-}$mice (Fig. $1 A$ ) [Li et al. (2007), their Fig. $1 A, B$ (http://www.jneurosci.org/cgi/content/ full/27/40/10849/F1)]. To explore the impact of chronically reduced $\gamma$-secretase activity on $\mathrm{A} \beta$ levels and deposition in vivo, $N c t^{+/-}$mice (50\% $\gamma$-secretase activity) or Aph-1 $a^{+/-}$mice (70\% activity) were crossed with $A P P^{\text {swe }} ; P S 1 \triangle E 9$ mice. The latter are a well characterized AD mouse model that expresses transgenes encoding familial AD-linked $\mathrm{APP}^{\text {swe }}$ and PS1 $\Delta$ E9. The authors examined A $\beta$ deposition and brain $A \beta$ aggregates using immunohistochemical analyses and filter trap assays. Interestingly, $\mathrm{A} \beta$ deposition in $A P P^{\text {swe }} ; P S 1 \triangle E 9 ; \mathrm{Nct}^{+/-}$mice and $A P P^{\text {swe }} ; P S 1 \Delta E 9 ; A p h-1 a^{+/-}$mice was reduced by amounts that approximated the level of $\gamma$-secretase reduction (Fig. $1 B$ ). By ELISA, soluble and insoluble $A \beta$ peptides from brain extracts of $A P P^{\text {swe }} ; P S 1 \triangle E 9$;
$\mathrm{Nct}^{+/-}$mice and APP ${ }^{\text {swe }} ; P S 1 \Delta E 9 ; A$ ph$1 a^{+/-}$mice were lower because of reduced $\gamma$-secretase activity, compared with $A P P^{\text {swe }} ; P S 1 \triangle E 9 ; \mathrm{Nct}^{+/+}$mice and $A P P^{\text {swe }}$; $P S 1 \Delta E 9 ; A p h-1 a^{+/+}$mice. Thus, a modest chronic decrement of $\gamma$-secretase activity of $30\left(\mathrm{Aph}-1 \mathrm{a}^{+/-}\right)$to $50 \%\left(\mathrm{Nct}^{+/-}\right)$was sufficient to attenuate $\mathrm{A} \beta$ accumulation. It would be interesting to see the lines with reduced $\gamma$-secretase crossed with an $\mathrm{A} \beta$ producing line that does not use PS1 $\Delta \mathrm{E} 9$. This would ensure that there were normal levels of wild-type PS1. Moreover, if crossed to lines that accumulate $\mathrm{A} \beta$ deposits at a slower rate, the moderate reduction of $\gamma$-secretase may be even more efficacious at reducing plaque load. Interestingly, even with overexpression of $\mathrm{PS} 1 \Delta \mathrm{E} 9, \mathrm{~A} \beta$ levels were reduced, suggesting that assembly of functionally active $\gamma$-secretase is still limited by endogenous components.

Next, the authors examined the side effects associated with chronic reduction of $\gamma$-secretase (Fig. 1C). Previous work demonstrated that Notch is involved in skin tumors, gastrointestinal abnormalities, and lymphopoiesis. Although most $\mathrm{Nct}^{+/-}$and $\mathrm{Nct}{ }^{+/-} ; \mathrm{PS} 1^{+/-}$mice developed skin abnormalities, squamous cell carcinoma, and showed shorter lifespan at least in part because of their increased tumor burden, $\mathrm{PS}^{+/-}$and Aph-1a $a^{+/-}$ mice did not develop skin cancer. Squamous cell hyperproliferation was rarely observed in $P S 1^{+/-}$and Aph-1a ${ }^{+/-}$mice and their life expectancies were similar to 
wild-type mice [Li et al. (2007), their Fig. 3 (http://www.jneurosci.org/cgi/content/ full/27/40/10849/F3)]. Splenomegaly caused by myeloid hyperproliferation and suppression of $\mathrm{T}$-cell proliferation was observed in old $\mathrm{Nct}^{+/-}$and $\mathrm{Nct}^{+/-}$; $\mathrm{PS}^{+/-}$mice [Li et al. (2007), their Fig. 4 (http://www.jneurosci.org/cgi/content/ full/27/40/10849/F4)]. Although a small percentage of old Aph-1a $a^{+/-}$mice showed enlargement of the spleen, splenomegaly was rarely observed in $P S 1^{+/-}$mice. These data indicate that a critical level of $\gamma$-secretase activity is required to protect epithelia from tumorigenesis: Inhibition of $\gamma$-secretase by up to $30 \%$ did not increase tumorigenesis in these mice, whereas $>50 \%$ reduction did. $\gamma$-secretase also was critical for myeloid and lymphocyte development because $>30 \%$ reduction of $\gamma$-secretase activity increased abnormal proliferation of granulocytes. The authors do not report whether similar findings were apparent in the lines crossed with $A P P^{\text {swe }} ; P S 1 \triangle E 9$, but comparisons would be difficult to resolve because of overexpression of PS1 $\Delta \mathrm{E} 9$ and compounded toxicity of the transgenic milieu. Moreover, because Notch is a poor substrate for PS1 $\Delta$ E9 (Zhang et al., 2005), interpretation of the results would be problematic.

Thus, Li et al. (2007) conclude that a $\gamma$-secretase reduction of $\sim 30 \%$ is sufficient to lower amyloid accumulation without compromising the processing of alternative substrates responsible for adverse side effects (Fig. $1 A-C$ ), suggesting the existence of an optimal window of therapeutic $\gamma$-secretase inhibition. Where does this strategy fit into possible $\mathrm{AD}$ treatments? Jankowsky et al. (2005) reported that when APP expression is conditionally reduced by $95 \%$ in mice after amyloid deposits have already formed, progression of amyloid pathology is halted, but the in situ load persists for months with little noticeable reduction (Jankowsky et al., 2005). Thus, $\gamma$-secretase inhibition may not be sufficient to reverse $\mathrm{AD}$ once the disease has fully manifested. However, partial inhibition of $\gamma$-secretase may reduce $\mathrm{A} \beta$ production sufficiently to prevent the progression of $\mathrm{AD}$ in late life, an idea also posited for statins, cholesterol-lowering agents that have been (controversially)

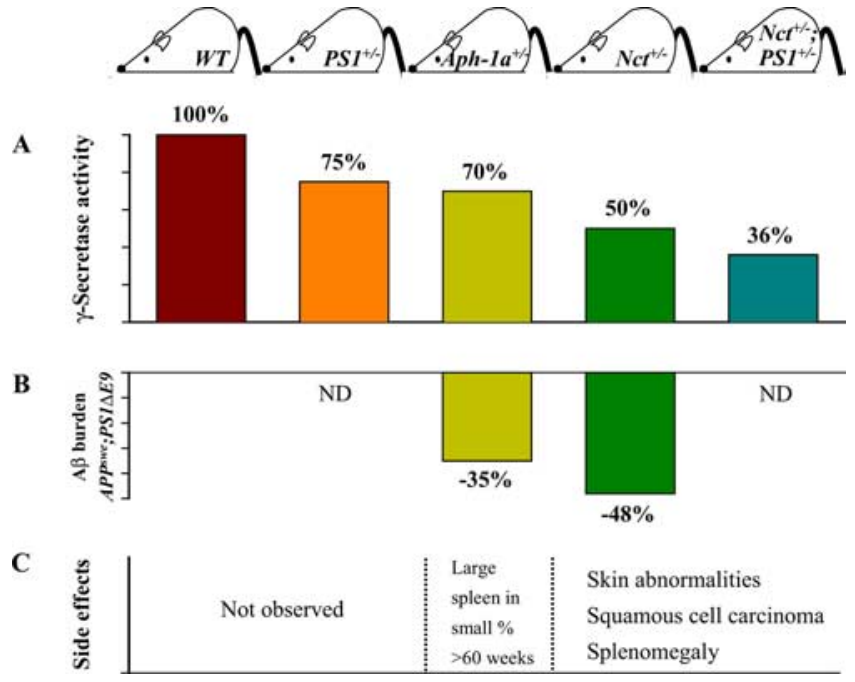

Figure 1. Moderate reduction (30\%) of $\gamma$-secretase activity attenuated $A \beta$ deposition with little or no side effects. $\boldsymbol{A}$, Mouse models with different levels of $\gamma$-secretase activity. $\boldsymbol{B}$, Reduction of Nct or Aph-1a expression attenuated A $\beta$ burden in APPswe; $P S 1 \triangle E 9$ mice. C, Moderate reduction of $\gamma$-secretase activity in $A p h-1 a^{+/-}$mice did not induce skin tumors or splenomegaly.

linked to a lower risk for acquiring AD. Moreover, because steady-state amyloid load is a function of both the accumulation and clearance of $\mathrm{A} \beta, \gamma$-secretase inhibition might be most efficacious when combined with other approaches such as $\mathrm{A} \beta$-based immunization or antibody strategies (Schenk et al., 1999). Last, because the factor responsible for cognitive decline in $\mathrm{AD}$ may not be the plaques themselves but rather smaller oligomeric species of $\mathrm{A} \beta$ (Lesne et al., 2006), it is possible that a cognitively therapeutic benefit may be apparent with low levels of $\gamma$-secretase inhibition. Clearly, additional work is required to understand the long term implications of $\gamma$-secretase inhibition in animal models using titrated doses of small molecule inhibitors. As work on AD progresses on many fronts, Li et al. (2007) bring fresh hope to an old strategy.

\section{References}

Guidos CJ (2002) Notch signaling in lymphocyte development. Semin Immunol 14:395-404.

Jankowsky JL, Slunt HH, Gonzales V, Savonenko AV, Wen JC, Jenkins NA, Copeland NG, Younkin LH, Lester HA, Younkin SG, Borchelt DR (2005) Persistent amyloidosis following suppression of Abeta production in a transgenic model of Alzheimer disease. PLoS Med 2:e355.

Lesne S, Koh MT, Kotilinek L, Kayed R, Glabe CG, Yang A, Gallagher M, Ashe KH (2006) A specific amyloid-beta protein assembly in the brain impairs memory. Nature 440:352-357.

Li T, Wen H, Brayton C, Laird FM, Ma G, Peng S, Placanica L, Wu TC, Crain BJ, Price DL, Eberhart CG, Wong PC (2007) Moderate reduction of gamma-secretase attenuates amyloid burden and limits mechanism-based liabilities. J Neurosci 27:10849-10859.

Milano J, McKay J, Dagenais C, Foster-Brown L, Pognan F, Gadient R, Jacobs RT, Zacco A, Greenberg B, Ciaccio PJ (2004) Modulation of notch processing by gamma-secretase inhibitors causes intestinal goblet cell metaplasia and induction of genes known to specify gut secretory lineage differentiation. Toxicol Sci 82:341-358.

Nicolas M, Wolfer A, Raj K, Kummer JA, Mill P, van Noort M, Hui CC, Clevers H, Dotto GP, Radtke F (2003) Notch1 functions as a tumor suppressor in mouse skin. Nat Genet 33:416-421.

Schenk D, Barbour R, Dunn W, Gordon G, Grajeda $\mathrm{H}$, Guido T, Hu K, Huang J, JohnsonWood K, Khan K, Kholodenko D, Lee M, Liao Z, Lieberburg I, Motter R, Mutter L, Soriano F, Shopp G, Vasquez N, Vandevert C, et al. (1999) Immunization with amyloid-beta attenuates Alzheimer-disease-like pathology in the PDAPP mouse. Nature 400:173-177.

Sisodia SS, St George-Hyslop PH (2002) gamma-Secretase, Notch, Abeta and Alzheimer's disease: where do the presenilins fit in? Nat Rev Neurosci 3:281-290.

Zhang L, Lee J, Song L, Sun X, Shen J, Terracina G, Parker EM (2005) Characterization of the reconstituted gamma-secretase complex from Sf 9 cells co-expressing presenilin 1 , nicastrin [correction of nacastrin], aph-1a, and pen-2. Biochemistry 44:4450-4457. 